\title{
Correlation Between Commuting and Migration in Daily Urban System of Pančevo (Vojvodina, Serbia)
}

\author{
Vesna Lukić ${ }^{1}$ \\ Received: July 2008 | Revised: November 2008 | Accepted: November 2008
}

\begin{abstract}
Spatial mobility of population is conditioned by numerous factors that affect process of migration. Individuals' decision about the type of spatial mobility depends on dominant influence that results from combination of external (mainly socio-economic) and internal (characteristics of migrant and his family) determinants of geographical mobility. Commuting can often be a step before or after definite migration, pointing to existence of mutual relationship between different types of spatial mobility of population. Starting hypothesis in this paper was that population which has already been involved in some form of mobility is more mobile than the so-called stationary part of population. Following this hypothesis, analysis of relationship between commuting and migration is elaborated in this paper on the example of daily urban system of Pančevo.
\end{abstract}

Key words: commuting, correlation, migration, Pančevo

\section{Introduction}

Individuals who take part in some form of spatial mobility can be divided into former movers and non-movers. There can be considerable differences in mobility behavior between those that migrate/commute for the first time and those with previous mobility experience. Although it is reasonable to believe that workers who have recently moved will be less likely to commute then the others, some empirical findings, that confirm the influence of migration history on probability of migration/commuting, are exactly the opposite. In Sweden, and in Catalonia in Spain, for example, individuals with previous experience of migration and/ or commuting are proved to be more mobility prone, especially when talking about interregional labour mobility. It is assumed that after having been mobile, person gains new information and faces relatively lower costs for additional mobility (Eliasson et al., 2003; Romani et al., 2003).

Relationship between different forms of population mobility is a complex one. That's why some authors include relation between migration and commuting in their typologies of migration (Gawryszenski, 1978; Termote, 1980, according to Roca, 1986). Reitsma and Vergossen also conect commuting and migration pointing to causal role of commuting within the decision on migration (Reitsma,Vergoossen, 1987). Zax and Kain (1991) demonstrate that commuting distance, acting as an important determinant of commut- ing, can stimulate mobility of workers and that non-optimal home-workplace locations can be improved either by a job change or a home change. When it's about commuting distance there are several opinions that commuting is a substitute to migration in intraregional mobility but is complement to migration when it is about interregional population mobility (Zax, 1994; Holmes, 1971).

Relationship between commuting and migration is also the subject of researches of national authors. According to author's knowledge, vajority of researches that are connected to relationship between commuting and migration in other regions in Serbia is based on questionnaires. The reason in probably lack of official record at the level needed for the analysis like this one. Ethnographic researches in the 1960 's of $20^{\text {th }}$ century in Mladenovac and Kolubara region as the centers of industrial and mining development, has partially encompassed also commuting issues, confirming that commuting has been preceded by migration of local type, inter-village or inter-municipal migration. Therefore the inhabitants have moved to certain settlement so commuting to Mladenovac and mining region of Kolubara would be easier to them (Radovanovic, 1968).

Having in mind the consequences that accrue from the scope, the composition and direction of migratory flows on spatial distribution of the population as well as rural and urban development, researching and studying of the rela- 
tions between commuting and migration, and the role of migration history in process of migration is very important. Such studies are significant as a pre-requisite for undertaking of relevant measures in order to influence social conditions which lead to decision on definite migration.

\section{Correlation Between Commuting and Migration in Pančevo}

Starting from the hypothesis that population which has already participated in some kind of spatial mobility is more prone to participate in commuting than the so-called stationary part of the population and for the purpose of exploring the relationship between commuting and migration we have analyzed commuters in Pančevo Municipality according to their mobility status. The emphasis has been made on the active commuters due to the fact that pupils/students commuters are not independent while deciding on the final relocation, since that decision most commonly depends on their parents. Therefore, the commuters which are not economically active have been excluded from this analysis. For purposes of the present study, we used data from the 2002 population census in the Republic of Serbia and a database on population obtained from the Republic of Serbia's Statistical Office. The indicated database was taken by the authors from the Republic of Serbia's Statistical Office in the form of an Access base compiled from individual records from which only personal information was omitted to ensure secrecy. The data were processed and transformed into data adequate for demographic studies. Moreover, data on population from Pančevo in 2002 not published in an official record at the level needed for the present study were obtained from the main base of the Republic of Serbia's Statistical Office through the assistance of that agency's information service.

Daily urban system of Pančevo consists of migrant commuters (8.409 or $51.4 \%$ ) and native commuters (7.946 or 48.6 $\%)$. Out of the total number of economically active commuters in Pančevo somewhat numerous are migrants commuters. Prevailing of the migrant population within daily urban system of Pančevo confirm theoretical knowledges about connection between different forms of population mobility. In the structure of convergent active commuters of the daily urban system of Pančevo $52.4 \%$ are native commuters and $47.6 \%$ are migrant commuters, whereas in the case of divergent active commuters of daily urban system of Pančevo greater difference on the count of the migrants can be seen and this relationship goes in the scope $38 \%: 62 \%$.

Settlements of the Pančevo Municipality with the exception of the municipal centre mostly attract migrant commuters. Native population prevails only within the structure of the commuters which go to work in Pančevo city. Considering their numerousity such situation reflects on total structure of the convergent flows of the daily urban system of Pančevo according to mobility status of commuters. Settlements Jabuka, Kačarevo and Banatski Brestovac have large participation of native population in the divergent commuting flows, whereas in settlements Banatsko Novo Selo, Dolovo, Glogonj, Pančevo and Starčevo there's the situation where migrant population in a large scope commute to work every day.

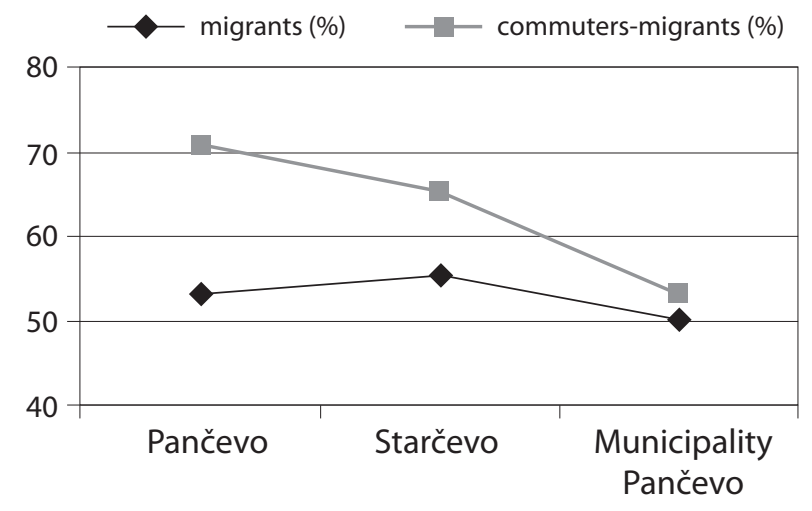

Figure 1 Population in Pančevo by mobility status 2002 Source: Statistical Office of the Republic of Serbia, specially processed data, 2007

As it can be seen in Figure 1 percentage of the migrant population is larger in the structure of Pančevo commuters in relation to total population of Pančevo Municipality. Even though this data are not completely comparable due to the differences in the age group and population's contingents' volume, they have been shown as a transparent indicator of the level of migrant population's participation in commuting. Related to the structure of the total population, migrant population participate more in the flows of economically active commuters which travel to work every day from eight out of ten settlements in Pančevo Munic ipality. Smaller part of migrant population that participate within local commuting results from non-existence of the need for the final relocation due to the shorter commuting time needed and smaller commuting distance in the case of local work center. Beside municipal center, suburban settlement Starčevo which is closest to Pančevo has large share of migrant population that participates in commuting. Yet $66 \%$ of the immigrants in the structure of active commuters traveling from Starčevo points to planned immigration of population to this suburban settlement of Pančevo. Thus the workers were able to ease participation in commuting to themselves by settling in the immediate closeness of Pančevo which is center of the work for the most inhabitants of Starčevo.

In order to study the relationship between commuting and definite migration as detailed as possible it was neccessary to take into consideration place of the origin of immigrant population and time of last migration while talking about commuters as the target population of this research. In the structure of the migrants of daily urban system of Pančevo the largest part consists of the immigrants from Central Serbia and then from former Yugoslav republics (see Table 1). This structure corresponds to the structure of the total migrant population of Pančevo Municipality where significant portion of the migrants had come from former Yugoslav republics either during colonization process after the Second World War or after the break-up of former Yugoslavia (Statistical Office of the Republic of Serbia, 2006).

Visible distinctions in convergent and divergent flows of migrant commuters can be seen in the share of immigrants from other settlements of the Municipality and im migrants from other republics/provinces. According to the previous place of residence there are far more immigrants 
Table 1 Convergent commuters-migrants by previous place of residence, 2002

\begin{tabular}{|c|c|c|c|c|c|c|c|c|c|}
\hline \multirow[b]{2}{*}{ Settlement } & \multirow[b]{2}{*}{ Total } & \multicolumn{8}{|c|}{ Previous place of residence: } \\
\hline & & $\begin{array}{l}\text { other settlement } \\
\text { of the same } \\
\text { municipality }\end{array}$ & $\%$ & $\begin{array}{c}\text { other } \\
\text { municipality } \\
\text { in Vojvodina }\end{array}$ & $\%$ & $\begin{array}{l}\text { Other } \\
\text { republic/ } \\
\text { province }\end{array}$ & $\%$ & $\begin{array}{c}\text { Other } \\
\text { municipalities } \\
\text { of ex SFRY }\end{array}$ & $\%$ \\
\hline B. Brestovac & 25 & 11 & 44.0 & 3 & 12.0 & 8 & 32.0 & 3 & 12.0 \\
\hline B. N. Selo & 29 & 8 & 27.6 & 8 & 27.6 & 6 & 20.7 & 7 & 24.1 \\
\hline Glogonj & 14 & 2 & 14.3 & 6 & 42.9 & 5 & 35.7 & 1 & 7.1 \\
\hline Dolovo & 20 & 6 & 30.0 & 4 & 20.0 & 8 & 40.0 & 2 & 10.0 \\
\hline Ivanovo & 11 & 7 & 63.6 & 2 & 18.2 & 0 & 0.0 & 1 & 9.1 \\
\hline Jabuka & 42 & 17 & 40.5 & 5 & 11.9 & 9 & 21.4 & 11 & 26.2 \\
\hline Kačarevo & 35 & 12 & 34.3 & 6 & 17.1 & 3 & 8.6 & 11 & 31.4 \\
\hline Omoljica & 33 & 13 & 39.4 & 6 & 18.2 & 6 & 18.2 & 5 & 15.2 \\
\hline Pančevo & 5,455 & 1,137 & 20.8 & 870 & 15.9 & 1,733 & 31.8 & 1,643 & 30.1 \\
\hline Starčevo & 54 & 17 & 31.5 & 9 & 16.7 & 18 & 33.3 & 10 & 18.5 \\
\hline Total & 5,718 & 1,230 & 21.5 & 919 & 16.1 & 1,796 & 31.4 & 1,694 & 29.6 \\
\hline
\end{tabular}

Source: Statistical Office of the Republic of Serbia, specially processed data, 2007.

from other settlements of Pančevo Municipality (local relocations) within the structure of convergent migrant commuters, related to the structure of divergent migrant commuters where there is considerably greater share of those who came from other republics/provinces. Thus local migrants mainly work in Pančevo City whereas other immigrants in larger scope commute to work outside Pančevo, mostly to Belgrade.

The biggest share of immigrants from other municipalities in Vojvodina can be seen in the structure of the commuters which work in Glogonj settlement and they mostly come from Opovo Municipality. The highest percentage of commuters that came originally from Serbia or Kosovo and Metohija work in Dolovo, whereas the most significant work center for those immigrated from former Yugoslav republics is Kačarevo settlement. Immigrants from former SFRY make majority within the daily flows of migrant labour force from Banatsko Novo Selo and Kačarevo settlements (see Table 2).
Apart from spatial, if we also include time dimension of the migration process into monitoring we can see that half of the active commuters that travel every day from Banatski Brestovac and Omoljica have migrated to those settlements during the last five years before 2002 Census, i.e. during the last war in former Yugoslavia. Even $29 \%$ of the commuters in Starčevo and $25 \%$ of them in Jabuka have migrated in the period 1997-2002. All of those commuters travel to work in Belgrade as the center of the higher range in the functional hierarchy of the settlements and the capital of the country with extremely powerful polarization influence. We can assume that, together with effects of the social networks and friendly/family bonds to the migrants that had come during previous periods from former Yugoslavia to Pančevo, lower prices of real estates and immediate closeness to Belgrade have also been important factors upon migration. Convenient location of Pančevo related to Belgrade has enabled the workers migrated in this period to choose commuting as a form of spatial mobility.

Table 2 Divergent commuters-migrants by previous place of residence, 2002

\begin{tabular}{|c|c|c|c|c|c|c|c|c|c|}
\hline \multirow[b]{2}{*}{ Settlement } & \multirow[b]{2}{*}{ Total } & \multicolumn{8}{|c|}{ Previous place of residence: } \\
\hline & & $\begin{array}{l}\text { other settlement } \\
\text { of the same } \\
\text { municipality }\end{array}$ & $\%$ & $\begin{array}{c}\text { other } \\
\text { municipality } \\
\text { in Vojvodina }\end{array}$ & $\%$ & $\begin{array}{l}\text { Other } \\
\text { republic/ } \\
\text { province }\end{array}$ & $\%$ & $\begin{array}{c}\text { Other } \\
\text { municipalities } \\
\text { of ex SFRY }\end{array}$ & $\%$ \\
\hline B.Brestovac & 22 & 8 & 36.4 & 1 & 4.5 & 9 & 40.9 & 4 & 18.2 \\
\hline B. N. Selo & 111 & 6 & 5.4 & 14 & 12.6 & 20 & 18.0 & 71 & 64.0 \\
\hline Glogonj & 96 & 3 & 3.1 & 8 & 8.3 & 40 & 41.7 & 44 & 45.8 \\
\hline Dolovo & 69 & 4 & 5.8 & 5 & 7.2 & 51 & 73.9 & 8 & 11.6 \\
\hline Ivanovo & 3 & 2 & 66.7 & 0 & 0.0 & 1 & 33.3 & 0 & 0.0 \\
\hline Jabuka & 39 & 6 & 15.4 & 3 & 7.7 & 16 & 41.0 & 14 & 35.9 \\
\hline Kačarevo & 183 & 6 & 3.3 & 20 & 10.9 & 56 & 30.6 & 100 & 54.6 \\
\hline Omoljica & 40 & 13 & 32.5 & 4 & 10.0 & 12 & 30.0 & 10 & 25.0 \\
\hline Pančevo & 1,936 & 121 & 6.3 & 327 & 16.9 & 851 & 44.0 & 612 & 31.6 \\
\hline Starčevo & 105 & 34 & 32.4 & 7 & 6.7 & 38 & 36.2 & 24 & 22.9 \\
\hline Total & 2,691 & 220 & 8.2 & 401 & 14.9 & 1,121 & 41.7 & 918 & 34.1 \\
\hline
\end{tabular}

Source: Statistical Office of the Republic of Serbia, specially processed data, 2007. 
Table 3 Local commuters-migrants by previous place of residence (\%), 2002.

\begin{tabular}{|l|c|c|}
\hline \multirow{2}{*}{ Settlement } & \multicolumn{2}{|c|}{ Previous place of residence: } \\
\cline { 2 - 3 } & $\begin{array}{c}\text { other settlement of the } \\
\text { same municipality, \% }\end{array}$ & $\begin{array}{c}\text { other municipality } \\
\text { in Vojvodina, \% }\end{array}$ \\
\hline B. Brestovac & 39.2 & 7.0 \\
\hline B. Novo Selo & 14.5 & 6.5 \\
\hline Glogonj & 24.7 & 10.6 \\
\hline Dolovo & 14.0 & 11.2 \\
\hline Ivanovo & 79.0 & 8.1 \\
\hline Jabuka & 22.4 & 4.3 \\
\hline Kačarevo & 16.9 & 6.9 \\
\hline Omoljica & 31.5 & 5.1 \\
\hline Pančevo & 40.1 & 17.2 \\
\hline Starčevo & 43.5 & 5.8 \\
\hline Total & 30.0 & 7.0 \\
\hline
\end{tabular}

Source: Statistical Office of the Republic of Serbia, specially processed data, 2007

Commuters which have changed their place of residence in the last five years (before 2002 Census) participate more in commuting than other categories of commuters of daily urban system of Pančevo. This cognitions that we have found while studying relation between commuting and migration in Vojvodina on Pančevo example, are agreeable to the findings from Catalonia, Spain. In Spain movers (workers who have changed their home in the past 5 years) tend to commute more than non-movers (Artis et al., 2000). Similarly to Serbia, high unemployment rates and high prices of real estate in this country discourage workers to quit their jobs or move, therefore workers keep commuting modality as the form of spatial mobility of population, even after the eventual relocation.

As we can see from Table 3 when talking about local commuting of labour force, which occur within territorial frames of Pančevo Municipality, the biggest number of immigrants from other municipalities in Vojvodina can be found in the structure of daily migration flows of labour force in Pančevo City which confirms its migration attractiveness in the context of wider region. On the contrary the highest share of immigrants which participate in local commuting is in Starčevo settlement due to its closeness to Pančevo City. Ivanovo settlement is specific due to its small total number of inhabitants and small number of the commuters. Therefore the data for this settlement should be looked at with reserve.

\section{A typology of settlements in Pančevo Municipality by relationship between commuting and migration}

Population in every settlement in Pančevo Municipality is involved in some form of spatial mobility. If we take different types of spatial mobility as the criteria for settlement typology, than we can extract five different groups of Pančevo settlements by levels of commuting and migration in general.

Only Pančevo City is in the first group of settlements with high values of general coefficient of commuting (ac-
Table 4 A typology of settlements in Pančevo Municipality by relationship between commuting and migration

\begin{tabular}{|c|c|c|c|c|}
\hline \multirow{3}{*}{\multicolumn{2}{|c|}{$\begin{array}{l}\text { Average annual rate } \\
\text { of migration balance } \\
\text { 1991-2002. (\%o) }\end{array}$}} & \multicolumn{3}{|c|}{ General coefficient of commuting } \\
\hline & & low & medium & high \\
\hline & & $<10 \%$ & $10-25 \%$ & $50 \%+$ \\
\hline \multirow{2}{*}{\multicolumn{2}{|c|}{ Negative }} & & Jabuka & \\
\hline & & & Kačarevo & \\
\hline \multirow{5}{*}{$\sum_{\substack{n \\
0}}^{\infty}$} & \multirow{3}{*}{$0.1-4.9$} & \multirow{2}{*}{$\begin{array}{l}\text { Banatski } \\
\text { Brestovac }\end{array}$} & Starčevo & \\
\hline & & & $\begin{array}{l}\text { Banatsko } \\
\text { Novo Selo }\end{array}$ & \\
\hline & & Omoljica & Glogonj & \\
\hline & \multirow{2}{*}{$5.0+$} & Ivanovo & & \multirow{2}{*}{ Pančevo } \\
\hline & & Dolovo & & \\
\hline
\end{tabular}

Source: CDI-IDN, 2004; Statistical Office of the Republic of Serbia, specially processed data, 2007

cording to Ilic J.,1970, the relation between the number of the inhabitants of one settlement that work in other settlement and the number of the workers of that settlement which live outside of it) and positive average annual rate of migration balance of $8,3 \%$. The second group consists of settlements with slightly decreased intensity of commuting and minimal immigration: Banatsko Novo Selo, Glogonj and Starčevo (see Table 4).

Dolovo and Ivanovo are settlements with values of the positive rate of migration balance above $5 \%$ and low values of commuting coefficient. Refugees from republics of ex SFRY, which make more than $10 \%$ of total population of Ivanovo, Banatsko Novo Selo and Starčevo, have had the most influence on positive rate of migration balance of those settlements. Starčevo is also the important center of local migrants - migrants from the territory of Pančevo Municipality (Statistical Office of the Republic of Serbia, 2004a). Settlements which have weak migration activity, with low positive rate of migration balance and low values of commuting coefficient are Banatski Brestovac and Omoljica. Larger participation of agricultural population within total population in Dolovo, Banatski Brestovac and Omoljica settlements affects onto weaker commuting of population compared to other settlements of Pančevo Municipality (Statistical Office of the Republic of Serbia, 2004b). The fifth group consists of the settlements with negative rate of migration balance and medium values of commuting coefficient: Jabuka and Kačarevo. After municipal center, Starčevo, Kačarevo i Jabuka are the strongest divergent centers of commuters and Pančevo Municipality. Negative rate of migration balance in Jabuka and Kačarevo in this period points to possible transfer of certain number of commuters to their settlement of work, which has brought to decrease in number of commuters from these settlements.

\section{Conclusion}

Researches on mutual relations between different forms of population spatial mobility and on the prevailing form of population mobility, are particularly significant from the aspect of migrations as the dominant factor of augmentation of the number of urban population in Vojvodina. The 
analysis of the relation between different forms of spatial mobility of population has shown, on the example of Pančevo, that population which had already been involved in some form of spatial mobility is more likely to participate in commuting, which also confirmed the cognitions of other authors about the influence of migration history onto migration activity. Definite migration preceded to commuting especially in the suburban settlement Starčevo. Commuting flows consist of numerous migrants relocated during the last five years (findings are agreeable to the findings from Catalonia, Spain - Artis et al., 2000).

Bearing in mind that part of commuting unvoidably substitutes into migration, monitoring of migration processes' trends and relationships between commuting and migration, as well as alleviation of conditions for commuting of economically active population represent one of the possible measures for maintaining local labour force. It's about local labor force which can not find appropriate job in their place of residence and for whom commuting could precede to definite migration. Therefore this kind of analysis should be more represented in national literature. For futher research it would be very interesting to explore relations and monitor the changes in relationship between commuting and migration in other spatial or administrative-territorial units as well, for which more detailed processed data about divergent and convergent commuting flows and migration history of commuters on the level of settlements should be available.

\section{Acknowledgment}

This study was supported by the Serbian Ministry of Science under project No. 146011.

\section{References}

Artis, M., Romani, J., Surinach, J. 2000. Determinants of Individual Commuting in Catalonia, 1986-1991: Theory and Empirical Evidence. Urban Studies 37, 8, 1431-1450. CDI-IDN, 2004. Population, 1-4, Annexes. (in Serbian)

Eliasson, K., Lindgren, U., Westerlund, O. 2003. Geographical Labor Mobility: Migration or Commuting? Regional Studies 37, 8, 827-837.
Holmes, J., 1971. External Commuting as a Prelude to Suburbanization. Annals of the Association of American Geographers 61, 4, 774-790.

Ilić, J., 1970. Characteristics of Functional relationships Between the City and its Surrounding Area, With special review of SR Serbia. Population, 3-4, 167-189, IDN-CDI. (in Serbian)

Radovanović, M., 1968. About Some Issues Concerning Ethnologic Studies of Commuting. Cvijic's Almanac in the memory of 1ooth anniversary of his birth, SASA, Department of Natural Sciences and Mathematics, 207-214, Belgrade. (in Serbian)

Reitsma, R., Vergossen, F. 1988. A Causal Tipology of Migration: The Role of Commuting. Regional Studies 22, 4, 331-340.

Roca, O. 1986. Migration of the workers in Zagreb: Geographic Aspect of Spatial Mobility and Issues. PhD dissertation, Zagreb.

Romani, J., Surinach, J., Artis, M., 2003. Are Commuting and Residential Mobility Decisions Simultaneous: The Case of Catalonia, Spain. Regional Studies 37, 8, 813-826.

Statistical Office of the Republic of Serbia, 2004a. 2002 Census of population, households and apartments, Book 8, "Population According to Migrational Characteristics - Data by Municipalities”, Belgrade. (in Serbian)

Statistical Office of the Republic of Serbia, 2004b. 2002 Census of population, households and apartments, Book 7, "Agricultural Population According to Ownership of Agricultural Farms, Profession and Gender - Data by Municipalities", Belgrade. (in Serbian)

Statistical Office of the Republic of Serbia, 2006. Documentation Table No.2., Immigrated population according to time of immigration, age at the time of immigration and area from which it had immigrated, 2002 Census, Belgrade. (in Serbian)

Statistical Office of the Republic of Serbia, 2007. Special Processed Data of 2002 Census of population, households and apartments, Belgrade. (in Serbian)

Zax, J. 1994. When is a move migration? Regional Science and Urban Economics 24, 3, pp.341-360.

Zax, J., Kain, J. 1991. Commutes, quits and moves. Journal of Urban Economics 28, 153-165. 